DOI: https://doi.org/10.24843/JFU.2019.v08.i01.p04

pISSN: 2301-7716; eISSN: 2622-4607

Jurnal Farmasi Udayana, Vol 8, No 1, Tahun 2019, 22-28

\title{
Optimasi Konsentrasi Pulvis Gummi Arabicum (PGA) sebagai Emulgator Formulasi Emulsi Ekstrak Rimpang Kunyit (Curcuma longa)
}

\author{
Subagia, I.K. ${ }^{*}$, Januarta, I.G.A. ${ }^{1}$, Arisanti, C.I.S. ${ }^{1}$, Samirana, P.O. ${ }^{1}$ \\ ${ }^{1}$ Program Studi Farmasi Fakultas Matematika dan Ilmu Pengetahuan Alam Universitas Udayana, Jalan Kampus \\ Unud, Jimbaran, 80364 \\ *E-mail: ikmsubagia15@gmail.com
}

\begin{abstract}
ABSTRAK
Penyakit maag atau gastritis merupakan suatu keadaan pendarahan atau peradangan mukosa lambung yang bersifat akut maupun kronis. Pengembangan sediaan emulsi ekstrak kunyit sebagai obat maag karena sifat fisiko kimia kurkumin pada ekstrak kunyit bersifat relatif tidak larut dalam air, sehingga dibuat sediaan emulsi untuk meningkatkan kelarutan kurkumin. Penggunaan Pulvis Gummi Arabicum (PGA) sebagai emulgator dapat menghasilkan emulsi yang sangat stabil. Variasi konsentrasi PGA yaitu 20, 25 dan 30\%. Ketiga formula yang dibuat memiliki warna coklat, berbau khas aroma mint, dan bertekstur kental yang stabil selama 7 hari penyimpanan. Nilai viskositas pada hari ke-1 dari tertinggi ke terendah yaitu dari F3, F2 dan F1 dengan nilai viskositas masing-masing 1013,33 $\pm 2,08$ cPs, 906,33 \pm 0,58 cPs dan $870,67 \pm 2,08$ cPs. Viskositas pada hari ke-3 dan ke-7 terjadi peningkatan pada ketiga formula. Hasil Pengujian redispersi pada formula 12 dan 3 berturut-turut sebanyak 6,67 $\pm 0,58$ kali, 4,33 \pm 1,15 kali dan $2,67 \pm 1,15$ kali pengocokan pada hari ke-1. Selanjutnya terjadi peningkatan jumlah pengocokan pada hari ke-3 dan ke-7 untuk sediaan dapat terdispersi kembali secara homogen. Pengujian tipe emulsi dilakukan dengan metode pengenceran pada ketiga formula menunjukkan tipe minyak dalam air pada ketiga formula dan stabil selama penyimpanan. Pada pengukuran $\mathrm{pH}$ hari ke-1 diperoleh $\mathrm{pH}$ emulsi yaitu 4,68 $\pm 0,03$, 4,71 $\pm 0,02$ dan 4,79 $\pm 0,01$ berturut turut F1, F2 dan F3. Pada hari berikutnya terjadi penurunan $\mathrm{pH}$ pada ketiga formula. Berdasarkan hasil penelitian, bertambahnya konsentrasi emulgator PGA menghasilkan emulsi yang lebih baik yang ditunjukkan dengan konsentrasi PGA 30\% menghasilkan emulsi dengan waktu redispersi lebih cepat dibandingkan konsentrasi PGA 20 dan 25\%.
\end{abstract}

Kata kunci: PGA, Emulsi, Curcuma longa, Gastritis

\section{ABSTRACT}

Gastritis is a condition of inflammation or bleeding of the gastric mucosa that can be acute or chronic. The development of turmeric extract emulsion preparations as an ulcer medicine because of the physico-chemical properties of curcumin in turmeric extract is relatively insoluble in water, so emulsion preparations are made to increase the solubility of curcumin. The use of Pulvis Gummi Arabicum (PGA) as an emulgator can produce very stable emulsions. PGA concentration variations are 20,25 and 30\%. The three formulas that are made have a brown color, smell of distinctive mint aroma, and have thick, stable texture for 7 days of storage. The viscosity value on day 1 from highest to lowest is from F3, F2 and F1 with viscosity values of 1013,33 $\pm 2,08 c P s, 906,33 \pm 0,58 c P s$ dan 870,67 $\pm 2,08$ cPs. Viscosity on days 3 and 7 increased in all three formulas. Redispersion test results in formula F1, F2 and F3 respectively 6,67 $\pm 0,58$ times, 4,33 \pm 1,15 times and 2,67 \pm 1,15 times on the 1st day. Furthermore, an increase in the number of shuffles on days 3 and 7 for the preparation can be dispersed back homogeneously. Emulsion type testing carried out by the dilution method on all three formulas showed the type of oil in water in all three formulas and was stable during storage. On measurement of $\mathrm{pH} 1$ day, the emulsion $\mathrm{pH}$ was 4,68 \pm 0,03, 4,71 $\pm 0,02$ and 4,79 $\pm 0,01$ respectively F1, F2 and F3. The following day there was a decrease in $p H$ on all three formulas. Based on the results of the study, increasing the 
DOI: https://doi.org/10.24843/JFU.2019.v08.i01.p04

pISSN: 2301-7716; eISSN: 2622-4607

Jurnal Farmasi Udayana, Vol 8, No 1, Tahun 2019, 22-28

PGA emulgator concentration resulted in a better emulsion. The $30 \%$ PGA concentration produced good emulsions with a faster redispersion time than 20 and 25\% PGA concentrations.

Keywords: PGA, Emulsion, Curcuma longa, Gastritis

\section{PENDAHULUAN}

Penyakit maag atau gastritis merupakan suatu keadaan pendarahan atau peradangan mukosa lambung yang bersifat akut maupun kronis. Gastritis terjadi akibat pola makan yang tidak teratur meliputi frekuensi makan, jumlah dan jenis makanan (Uripi, 2001). Disisi lain, kunci pengobatan penyakit gastritis yaitu dapat mengontrol produksi asam lambung (Wijoyo, 2009). Salah satu pengobatan tradisional untuk penyakit gastritis yaitu bersumber pada Usada Bali. Salah bahan alam dalam usada bali yang dapat mengobati penyakit perut kembung karena masuk angin atau maag adalah kunir warangan atau Kunyit (Nala, 1990).

Tanaman kunyit dengan nama latin Curcuma longa secara tradisional digunakan sebagai pengobatan radang, mencret, sakit kuning, gastritis, ulkus lambung dan sakit perut. Kandungan zat aktif kunyit yaitu kurkuminoid (Hartati, 2013). Yadav et al., (2013) menyatakan kurkumin dapat sebagai agen antiulcer sebagai penanganan gastritis. Selain itu Santoso (2017) juga menyatakan bahwa pemberian ekstrak kunyit (C. Domestica Val.) mempunyai sifat gastroprotektor sehingga dapat melindungi mukosa lambung tikus. Hal ini dikuatkan dengan hasil penelitian Savaringal dan Sanalkumar (2018) yang mengungkapkan bahwa ekstrak rimpang Curcuma longa memiliki aktivitas anti-ulkus yang signifikan yaitu dosis $500 \mathrm{mg} / \mathrm{Kg}$ BB dan 1000 $\mathrm{mg} / \mathrm{Kg} \mathrm{BB}$ pada tikus galur wistar.

Pengembangan sediaan farmasi ekstrak kunyit sebagai obat maag memiliki banyak kekurangan apabila dilihat dari sifat zat aktif yang terdapat dalam ekstrak kunyit yaitu kurkumin. Senyawa kurkumin relatif tidak larut dalam air, sedikit larut dalam benzena dan kloroform, larut dalam alkohol dan asam asetat glasial (Lina, 2008 ; Parthasarathy et al., 2008). Berdasarkan permasalahan tersebut, perlu dilakukan suatu formulasi sediaan farmasi yang dapat meningkatkan kelarutan kurkumin, salah satunya adalah sediaan emulsi. Pemilihan bentuk sediaan emulsi karena kurkumin bersifat sukar larut dalam air dan lebih mudah larut dalam minyak.

Formulasi sediaan emulsi diperlukan bahan emulgator untuk menstabilkan sediaan emulsi dan fase minyak untuk melarutkan zat aktif kurkumin. Dalam penelitian ini digunakan Pulvis Gummi Arabicum (PGA) sebagai emulgator dan fase minyak berupa olive oil. Penggunaan PGA dapat menghasilkan emulsi yang sangat stabil, tidak terlalu kental, dan dapat meningkatkan stabilitas dengan peningkatan viskositas. Menurut Saifullah dan Aziz (2011), emulsi menggunakan emulgator PGA sebagai bahan pengemulsi memberikan kestabilan emulsi yang tinggi. Berdasarkan permasalahan di atas, perlu dilakukan penelitian mengenai optimasi variasi konsentrasi PGA 20, 25 dan 30\% dalam formulasi emulsi ekstrak kunyit (Curcuma domestica Val.)

\section{METODE PENELITIAN}

\section{Alat dan Bahan}

\section{a. Alat}

Alat yang digunakan dalam penelitian ini meliputi timbangan analitik (Adam AFP-360L), blender (Philips), oven (Binder), Viscometer Brookfield DV-E, pH-meter digital (Mettler Toledo), botol kaca gelap, kertas perkamen, sendok tanduk, mortir dan stamper, kertas saring, batang pengaduk, serta alat gelas (Pyrex). 
DOI: https://doi.org/10.24843/JFU.2019.v08.i01.p04

pISSN: 2301-7716; eISSN: 2622-4607

Jurnal Farmasi Udayana, Vol 8, No 1, Tahun 2019, 22-28

\section{b. Bahan}

Bahan yang digunakan meliputi serbuk kunyit, olive oil (Bratachem), PGA (Bratachem), aquadest (Bratachem), Sorbitol (Bratachem), Na. benzoat (Bratachem), etanol 96\% (Bratachem), as. sitrat (Bratachem), dan essence mint (Labor).

\section{Penyiapan Ekstrak}

Rimpang Kunyit yang diperoleh dari daerah Karangasem dibersihkan terlebih dahulu dengan air, dipotong kecil-kecil, dikeringkan. Rimpang kering diserbukkan dengan blender. Serbuk rimpang kunyit sebanyak $300 \mathrm{~g}$ kemudian dimaserasi dengan etanol 96\% sebanyak $1800 \mathrm{~mL}$ selama tiga hari sambil diaduk. Dilakukan remaserasi sebanyak 2 kali masing-masing selama 1 hari. Maserat yang diperoleh dikumpulkan. Selanjutnya, maserat disaring dan diupakan dengan oven suhu $40-50^{\circ} \mathrm{C}$ hingga diperoleh ekstrak kental.

\section{Rancangan Formula dan Pembuatan Emulsi F1 dan F2}

Formula emulsi yang dibuat meliputi zat aktif (ekstrak rimpang kunyit), fase minyak (olive oil), Emulgator (PGA), pemanis (sorbitol), dapar (as. sitrat), Alkalizing agent

Tabel 1.Formula Sediaan Emulsi Ekstrak Etanol Rimpang Kunyit

\begin{tabular}{cccc}
\hline Bahan & \multicolumn{3}{c}{ Konsentrasi (b/v) } \\
\hline & F1 & F2 & F3 \\
\hline $\begin{array}{c}\text { Ekstrak etanol } \\
\text { rimpang } \\
\text { kunyit }\end{array}$ & 20 & 20 & 20 \\
\hline Olive oil & 20 & 20 & 20 \\
\hline PGA & 20 & 25 & 30 \\
\hline Sorbitol & 15 & 15 & 15 \\
\hline Asam sitrat & 0,25 & 0,25 & 0,25 \\
\hline Natrium sitrat & 0,25 & 0,25 & 0,25 \\
\hline Na. benzoat & 0,1 & 0,1 & 0,1 \\
\hline Ess. mint & q.s. & q.s. & q.s. \\
\hline Air sampai & Ad 100 & Ad 100 & Ad 100 \\
\hline
\end{tabular}

(Na. sitrat), pengawet ( $\mathrm{Na}$. Benzoat), corringen odoris (Ess. Mint) dan pelarut (Air). Pada penelitian ini, emulsi yang mengandung ekstrak rimpang kunyit dibuat dengan variasi PGA 20, 25 dan $30 \%$ (Tabel 1).

Sediaan emulsi pada penelitian ini menggunakan metode gom basah (4 bagian minyak : 2 bagian gom : 1 bagian air). Pertama olive oil dan ekstrak rimpang kunyit dituang ke dalam mortir, kemudian PGA didispersikan hingga merata dalam minyak. Kemudian diaduk dengan cepat hingga terbentuk korpus emulsi. Sorbitol, as. sitrat, Na. benzoat, na. sitrat dan essence mint dilarutkan dalam air secukupnya, kemudian secara perlahan-lahan dimasukkan ke dalam korpus emulsi, terakhir ditambahkan air hingga tanda batas (Ansel, 1989).

\section{Evaluasi Sediaan Emulsi}

\section{a. Uji Organoleptis}

Uji organleptis dilakukan dengan mengamati bau, warna, dan bentuk/tekstur sediaan pada hari ke-1, 3 dan 7 .

\section{b. Uji Viskositas}

Pengukuran dilakukan menggunakan viskometer Brookfield pada pada suhu ruang $\left(27^{\circ} \mathrm{C}\right)$ menggunakan spindel no.4 pada kecepatan $100 \mathrm{rpm}$. Pengukuran dilakukan pada hari ke-1, 3, dan 7 (Febrina dkk., 2007).

\section{c. Uji Redispersi}

Sediaan emulsi dimasukkan ke dalam botol $100 \mathrm{ml}$. Dilakukan pengocokan dengan cara membalikkan botol dengan sudut $180^{\circ}$, dicatat jumlah pengocokan yang diperlukan hingga emulsi terdispersi dengan baik. Pengukuran dilakukan pada hari ke-1, 3, dan 7 (Febrina dkk., 2007).

\section{d. Uji Tipe Emulsi}

Uji tipe emulsi dilakukan dengan melarutkan emulsi ke dalam air. Diamati apakah emulsi tercampur sempurna dengan air, maka emulsi termasuk tipe $\mathrm{M} / \mathrm{A}$ sedangkan bila emulsi tidak bercampur dengan sempurna 
DOI: https://doi.org/10.24843/JFU.2019.v08.i01.p04

pISSN: 2301-7716; eISSN: 2622-4607

Jurnal Farmasi Udayana, Vol 8, No 1, Tahun 2019, 22-28

maka tipe emulsi A/M. Pengukuran dilakukan pada hari ke-1, 3, dan 7 (Martin et al., 1993).

\section{e. Uji pH}

Uji $\mathrm{pH}$ dilakukan dengan alat $\mathrm{pH}$ meter. Elekroda dikalibrasi dengan larutan $\mathrm{pH} 4,01$ dan 7,00. Selanjutnya elektroda dicelupkan ke dalam sediaan. Dicatat $\mathrm{pH}$ yang muncul pada layar. Pengukuran dilakukan pada hari ke-1, 3, dan 7 (Depkes RI, 1995).

\section{HASIL}

Ekstrak etanol rimpang kunyit yang dihasilkan memiliki warna kuning kecokelatan, tekstur kental dan berbau khas kunyit. Rendemen yang diperoleh sebesar 24,385\%. Hasil uji organoleptis ditunjukkan pada Tabel 2 dan Hasil uji viskositas, redispersi, tipe emulsi dan $\mathrm{pH}$ tercantum dalam tabel 3 .

\section{PEMBAHASAN}

Pengembangan sediaan farmasi ekstrak kunyit sebagai penanganan penyakit maag diformulasikan kedalam bentuk emulsi. Namun, Ekstrak kunyit memiliki kekurangan apabila dilihat dari sifat zat aktif di dalam ekstrak kunyit yaitu kurkumin, salah satunya adalah senyawa kurkumin relatif tidak larut dalam air (Lina, 2008). Dipilihnya bentuk emulsi untuk meningkatkan kelarutan kurkumin yang terdapat di dalam ekstrak rimpang kunyit. Sediaan emulsi merupakan sediaan dengan dua fase yang tidak saling campur, dimana salah satu cairannya terdispersi dalam cairan lain dan distabilkan oleh emulgator (Depkes RI, 1995).

Tabel 2. Hasil Uji Organoleptis Emulsi Ekstrak Kunyit

\begin{tabular}{ccccc}
\hline \multirow{2}{*}{ Formula } & \multirow{2}{*}{ Pemeriksaan } & \multicolumn{3}{c}{ Pengamatan Hari Ke- } \\
\cline { 2 - 5 } & & 1 & 3 & 7 \\
\hline \multirow{2}{*}{ F1 } & warna & Coklat & Coklat & Coklat \\
\cline { 2 - 5 } & Bau & Mint & Mint & Mint \\
\cline { 2 - 5 } & Bentuk/ & Cairan & Cairan & Caira \\
& Tekstur & Kental & Kental & Kental \\
\hline F2 & warna & Coklat & Coklat & Coklat \\
\hline
\end{tabular}

\begin{tabular}{ccccc}
\hline & Bau & Mint & Mint & Mint \\
\cline { 2 - 5 } & Bentuk/ & Cairan & Cairan & Caira \\
Tekstur & Kental & Kental & Kental \\
\hline \multirow{4}{*}{ F3 } & warna & Coklat & Coklat & Coklat \\
\cline { 2 - 5 } & Bau & Mint & Mint & Mint \\
\cline { 2 - 5 } & Bentuk/ & Cairan & Cairan & Caira \\
& Tekstur & Kental & Kental & Kental \\
\hline
\end{tabular}

Tabel 3. Hasil Uji Viskositas, Redispersi, Tipe Emulsi dan pH Emulsi Ekstrak Kunyit

Pengamatan Hari Ke-

\begin{tabular}{|c|c|c|c|c|}
\hline \multirow[t]{2}{*}{ Pemeriksaan } & \multirow[t]{2}{*}{ Formula } & \multicolumn{3}{|c|}{ (Rata-rata $\pm \mathrm{SD})$} \\
\hline & & 1 & 3 & 7 \\
\hline \multirow{4}{*}{$\begin{array}{l}\text { Viskositas } \\
\text { (cPs) }\end{array}$} & F1 & $\begin{array}{r}870,67 \\
+\quad 208\end{array}$ & $\begin{array}{l}878,33 \\
+252\end{array}$ & $\begin{array}{r}883,00 \\
+265\end{array}$ \\
\hline & & & 01267 & 02033 \\
\hline & F2 & $\pm 0,58$ & $\pm 2,52$ & $\pm 2,52$ \\
\hline & F3 & $\begin{array}{c}1013,33 \\
\pm 2,08\end{array}$ & $\begin{array}{c}1019,67 \\
\pm 2,08\end{array}$ & $\begin{array}{r}1024,67 \\
\pm 1,15\end{array}$ \\
\hline \multirow{3}{*}{$\begin{array}{l}\text { Redispersi } \\
\text { (X) }\end{array}$} & F1 & $\begin{array}{c}6,67 \pm \\
0,58\end{array}$ & $\begin{array}{c}8,33 \pm \\
0,58\end{array}$ & $\begin{array}{c}10,67 \pm \\
1,15\end{array}$ \\
\hline & $\mathrm{F} 2$ & $\begin{array}{c}4,33 \pm \\
1,15\end{array}$ & $\begin{array}{c}5,33 \pm \\
0,58\end{array}$ & $\begin{array}{c}6,00 \pm \\
1,00\end{array}$ \\
\hline & $\mathrm{F} 3$ & $\begin{array}{c}2,67 \pm \\
1,15\end{array}$ & $\begin{array}{c}3,33 \pm \\
0,58\end{array}$ & $\begin{array}{c}4,00 \pm \\
1,00\end{array}$ \\
\hline \multirow{3}{*}{ Tipe Emulsi } & $\mathrm{F} 1$ & $\mathrm{M} / \mathrm{A}$ & $\mathrm{M} / \mathrm{A}$ & $\mathrm{M} / \mathrm{A}$ \\
\hline & F2 & $\mathrm{M} / \mathrm{A}$ & $\mathrm{M} / \mathrm{A}$ & $\mathrm{M} / \mathrm{A}$ \\
\hline & F3 & $\mathrm{M} / \mathrm{A}$ & $\mathrm{M} / \mathrm{A}$ & $\mathrm{M} / \mathrm{A}$ \\
\hline \multirow{3}{*}{$\mathrm{pH}$} & $\mathrm{F} 1$ & $\begin{array}{c}4,68 \pm \\
0,03\end{array}$ & $\begin{array}{c}4,63 \pm \\
0,03\end{array}$ & $\begin{array}{c}4,60 \pm \\
002\end{array}$ \\
\hline & $\mathrm{F} 2$ & $\begin{array}{c}4,71 \pm \\
0,02\end{array}$ & $\begin{array}{c}4,71 \pm \\
0,01\end{array}$ & $\begin{array}{c}4,68 \pm \\
0,01\end{array}$ \\
\hline & F3 & $\begin{array}{c}4,79 \pm \\
0,01\end{array}$ & $\begin{array}{c}4,78 \pm \\
0,02\end{array}$ & $\begin{array}{c}4,78 \pm \\
0,01\end{array}$ \\
\hline
\end{tabular}

Keterangan : M/A = Minyak dalam Air

$$
\mathrm{X}=\text { Jumlah Kali Pengocokan }
$$

Sampel yang digunakan adalah bagian rimpang pada kunyit. Rimpang kunyit dibuat dalam bentuk serbuknya untuk memudahkan dan mengoptimalkan penarikan senyawa kurkumin dari matriksnya. Hal ini dikarenakan dalam bentuk serbuk memungkinkan kontak matriks dengan pelarut semakin besar akibat luas permukaan bahan yang semakin besar (Harbone, J.B, 1967; Tambun dkk., 2016). Metode yang digunakan dalam tahap ekstraksi ini yaitu Maserasi (Kusmardiyani dan Nawawi, 1992). Pelarut yang digunakan yaitu etanol 
DOI: https://doi.org/10.24843/JFU.2019.v08.i01.p04

pISSN: 2301-7716; eISSN: 2622-4607

Jurnal Farmasi Udayana, Vol 8, No 1, Tahun 2019, 22-28

96\%. Metode maserasi ini dilakukan karena prosesnya yang mudah dan sederhana. Bejana maserasi ditutup dengan plastik ikan dan dibungkus dengan lakban hitam sehingga terhindar dari sinar matahari langsung. Hal ini bertujuan untuk menghindari terjadinya reaksi yang dikatalisis cahaya. Selain itu, pada tahap maserasi dilakukan pengandukan sesekali. Fungsi pengadukan yaitu meratakan konsentrasi cairan diluar serbuk simplisia, dengan pengadukan dapat menjaga konsentrasi antara larutan di luar sel dengan larutan di dalam sel. Jumlah serbuk kunyit yang digunakan sebanyak 300 gram dan Volume pelarut yang digunakan dalam maserasi pertama adalah 1,8 liter dan dilakukan remaserasi sebanyak 2 kali untuk remaserasi membutuhkan sebanyak 1 liter pelarut. Perbandingan simplisia yang meningkat terhadap cairan pengekstraksi, memungkinkan memperoleh rendemen yang lebih besar (Voigt, 1995; Dewi dkk., 2016).

Sediaan emulsi pada penelitian ini menggunakan metode gom basah (4 bagian minyak : 2 bagian gom : 1 bagian air). Pertama olive oil dan ekstrak rimpang kunyit dituang ke dalam mortir, kemudian PGA didispersikan hingga merata dalam minyak. Kemudian diaduk cepat hingga terbentuk korpus emulsi. Sorbitol, as. sitrat, Na. benzoat, na. sitrat dan essence mint dilarutkan dalam air secukupnya, kemudian secara perlahan-lahan dimasukkan ke dalam korpus emulsi, terakhir ditambahkan air hingga tanda batas (Ansel, 1989).

Pada proses emulsifikasi terjadi suatu proses homogenisasi dimana terjadi perubahan ukuran fase terdispersi (globul) yang semakin mengecil sehingga terdispersi baik pada medium pendispersinya. Homogenisasi secara mekanik ternyata mampuu mengurangi ukuran globul sehingga penyebaran PGA secara merata. Prinsip kerja homogenisasi mekanik yaitu dengan cara menggerus partikel besar dengan komponen yang bergerak sehingga menghasilkan partikel berukuran yang lebih kecil (Intan et al., 2012). Penggunaan natrium benzoate dengan konsentrasi 0,1\% bertujuan untuk mencegah tumbuhnya mikroorganisme pada sediaan emulsi, dimana emulsi yang dibuat adalah emulsi tipe minyak dalam air. Air merupakan media yang cepat ditumbuhi mikroorganisme sehingga dipilih natrium benzoate sebagai pengawet yang larut dalam air. Penggunaan asam sitrat dan natrium sitrat pada formula bertujuan sebagai buffer dan alkalizing agent sehingga $\mathrm{pH}$ sediaan tetap terkontrol (Rowe et al., 2009).

Viskositas merupakan satuan ukuran resistensi suatu zat cair untuk mengalir. Pengujian viskositas sediaan emulsi ini menggunakan viskometer brookfield dengan spindle nomor empat kecepatan $100 \mathrm{rpm}$. Hasil uji viskositas menunjukkan bahwa pada hari ke-1 viskositas dari tertinggi ke terendah yaitu dari F3, F2 dan F1 dengan nilai viskositas masing-masing 1013,33 $\pm 2,08 \mathrm{cPs}, 906,33 \pm$ 0,58 cPs dan 870,67 \pm 2,08 cPs. Viskositas pada hari ke-3 dan ke-7 terjadi peningkatan pada ketiga formula, dimana pada hari ke-7 viskositas sediaan mencapai $883,00 \pm 2,65 \mathrm{cPs}$ pada F1, 920,33 $\pm 2,52$ cPs pada F2 dan $1024,67 \pm 1,15$ cPs pada F3 (Tabel 2.). Peningkatan viskositas terjadi karena adanya reaksi antara PGA dengan air yang kemudian membentuk polimer-polimer dalam sediaan.

Hasil uji redispersi menunjukkan bahwa formula F1 membutuhkan jumlah pengocokan yang paling banyak untuk dapat terdispersi kembali secara homogen. Sedangkan pada formula F3 jumlah pengocokan semakin sedikit. Dilihat pada hari ke-3 dan ke-7 diperlukan jumlah pengocokan yang lebih banyak dibandingkan hari ke-1 pada uji redispersi. Hal ini disebabkan karena viskositas sediaan pada hari ke-3 dan ke-7 semakin meningkat sehingga akan lebih sulit untuk sediaan terdispersi homogen. Sehingga diperlukan pengocokan yang lebih banyak agar dapat terdispersi kembali secara homogen. 
DOI: https://doi.org/10.24843/JFU.2019.v08.i01.p04

pISSN: 2301-7716; eISSN: 2622-4607

Jurnal Farmasi Udayana, Vol 8, No 1, Tahun 2019, 22-28

Uji fisiko kimia sediaan berupa uji tipe emulsi dapat dinilai dari fase yang terbentuk. Apabila minyak sebagai fase terdispersi dan air sebagai fase pendispersi, maka tipe ini disebut emulsi minyak dalam air (M/A). Sebaliknya, jika air fase terdispersi dan minyak fase pendispersi, maka tipe ini disebut emulsi air dalam minyak (A/M) (Lachman et al., 1994). Uji tipe emulsi dilakukan dengan cara pengenceran dengan air. Dengan pengenceran dapat dilihat emulsi larut dalam pengencer air maka emulsi yang terbentuk merupakan emulsi minyak di dalam air. Hal ini menandakan memang benar emulsi yang dibuat merupakan emulsi minyak dalam air yang ditunjukkan dengan tipe emulsi sediaan pada ketiga formula adalah tipe minyak dalam air (M/A). Pengujian selanjutnya yaitu pengujian $\mathrm{pH}$ sediaan. Hari ke-1 diperoleh $\mathrm{pH}$ emulsi yaitu 4,68 \pm 0,03, 4,71 $\pm 0,02$ dan 4,79 $\pm 0,01$ berturut turut F1, F2 dan F3. Pada hari berikutnya terjadi penurunan $\mathrm{pH}$ pada ketiga formula. Namun, walaupun demikian ketiga sediaan emulsi ini sudah memenuhi rentang $\mathrm{pH}$ yang persyaratkan.

\section{KESIMPULAN}

Berdasarkan hasil penelitian menunjukkan bahwa bertambahnya konsentrasi emulgator PGA menghasilkan emulsi yang lebih baik. Konsentrasi PGA 30\% menghasilkan emulsi yang lebih baik dengan waktu redispersi lebih cepat dibandingkan konsentrasi 20 dan $25 \%$.

\section{UCAPAN TERIMAKASIH}

Penulis mengucapkan terimakasih kepada dosen pembimbing, keluarga penulis, teman-teman dan semua pihak yang telah sangat membantu dalam penelitian ini.

\section{DAFTAR PUSTAKA}

Anief, M. 2006. Ilmu Meracik Obat. Yogyakarta: Gadjah Mada University Press.

Ansel, H.C., 1989. Pengatar Bentuk sediaan Farmasi. Edisi 4. UI Press. Jakarta.
Depkes RI. 1995. Farmakope Indonesia Edisi IV. Jakarta: Departeman Kesehatan Republik Indonesia.

Dewi, P. J. N., Amna, H., Sri, M. 2016. Pengaruh Umur Panen dan Tingkat Maserasi Terhadap Kandungan Kurkumin dan Aktivitas Antioksidan Ekstrak Kunyit (Curcuma domestica Val.). Jurnal Rekayasa dan Manajemen Agroindustri. Vol. 4 (2) : 101-111.

Febrina, E., D. Gozali, dan T. Rusdiana. 2007. Formulasi Sediaan Emulsi Buah Merah (Pandanus Conoideus Lam.) sebagai Produk Antioksidan Alami. Penelitian Peneliti Muda (Litmud) Unpad. Bandung: Padjajaran.

Harborne JB. 1973. Phytochemical Method. London: Chapman and Hall, Ltd.

Hartati, S.Y. 2013. Khasiat Kunyit sebagai Obat Tradisional dan Manfaat Lainnya. Warta Penelitian dan Pengembangan Tanaman Industri. Vol. 19(2): 5-9.

Intan, K., Hidayat, T., dan Setiabudy, D. 2012. Pengaruh kondisi homogenisasi terhadap karakteristik fisik dan mutu santan selama penyimpanan. Jurnal Litri. Vol. 18(1): 34-35.

Kusmardiyani, S. dan A. Nawawi. 1992. Kimia Bahan Alam. Jakarta : Pusat Antar Universitas Bidang Ilmu Hayati.

Lachman, L.; Lieberman, H. A.; Kanig, J. L. 1994. Teori dan Praktek Farmasi Industri. Jilid 2. Penerjemah Siti Suyatmi. UI Press. Jakarta.

Lina. 2008. Standarisasi Ekstrak Rimpang Kunyit (Curcuma domestica Val.). Skripsi. Yogyakarta: Universitas Sanata Darma.

Martin, A., Swarbrick, J., Commarata, A. 1993. Farmasi Fisik 2. Edisi Ketiga. Jakarta: UI Press. 
Subagia, dkk.

DOI: https://doi.org/10.24843/JFU.2019.v08.i01.p04

pISSN: 2301-7716; eISSN: 2622-4607

Jurnal Farmasi Udayana, Vol 8, No 1, Tahun 2019, 22-28

Nala, N. 1990. Usada Bali. Denpasar: PT. Upada Sastra.

Parthasarathy, V. A., Chempakan, B., Zachariah, T. J. 2008. Chemistry of Spices. CABI : Oxford.

Rowe, R. C., P. J. Sheskey, and M. E. Quinn. 2009. Handbook of Pharmaceutical Excipients.Sixth Edition. Washington DC: Pharmaceutical Press.

Saifullah M, Aziz MG. 2011. Development Of Orange Flavour Emulsion. Journal Bangladesh Agriculture. Vol. 9(2): 291-296.

Santoso, Joko. 2017. Efektivitas Infusa Rimpang Kunyit (Curcuma domestica Val.) Sebagai Gastroprotektor Pada Tikus Dengan Model Tukak Lambung. Jurnal Permata Indonesia. Vol. 8(1): 34-44.

Savaringal J. P. dan Sanalkumar K. B. 2018. Anti-ulcer effect of rhizome of Curcuma longa Linn, by the method ofpyloric ligation. International Journal of Basic and Clinical Pharmacology. Vol. 7(1): 20-26.

Tambun, R., Harry L., Christika P., dan Ester Manurung. 2016. Pengaruh Ukuran Partikel, Waktu Dan Suhu Pada Ekstraksifenol Dari Lengkuas Merah. Jurnal Teknik Kimia USU. Vol. 5(4): 5356.

Uripi, Vera. 2001. Menu untuk Penderita Hepatitis \& Gangguan Saluran Pencernaan. Jakarta: Puspa Swara.

Voight, R. 1995. Buku Pengantar Teknologi Farmasi. Edisi V. Yogyakarta: Universitas Gadjah Mada Press.

Wijoyo. 2009. 15 Ramuan Penyembuh Maag. Jakarta: Bee Media Indonesia.

Yadav, R. P. and G. Tarun. 2017. Versatility of turmeric: A review the golden spice of life. Journal of Pharmacognosy and Phytochemistry. Vol. 6(1): 41-46 